\title{
Governance Arrangements and Governmental Performance: The Impact of Organizational Arrangements
}

\author{
PETER R. GLUCK \\ University of Michigan-Flint
}

The urban crisis has been viewed by students of urban affairs as a crisis of performance and a crisis of confidence. As a crisis of performance, the urban crisis is vicwed from the perspective of delivering appropriate levels and mixes of public goods and services to residents of urban communities. Equally important is the factor of cost. Services must not only be produced and provided at the proper levels and combinations, but this must be done within reasonable economic limits. The cost of providing public goods and services in urban areas is increasing at a much greater rate than the ability of urban governments to raise the revenue necessary to foot the bill. As a crisis of confidence, the urban crisis is seen as the result of the increasing isolation and insulation of elected and appointed officials, as well as administrative agencies, from the citizens who reside in the communities these officials and agencies serve. The perceived break. down in communication and contact between public officials and the public has caused governmental institutions to lose their ability to respond to the needs of the public. As a result, policy-making occurs under conditions of minimal information concerning citizen needs and preferences. Under such circumstances it is hardly surprising to hear the charge that public officials and public policy are unresponsive to the real needs of citizens.

Discounting pejorative rhetoric that frequently accompanies discussion of the urban crisis, valid demands for economy and efficiency in the production and provision of public goods and services, as well as for greater institutional responsiveness to citizen needs and preferences in policy-making, have been voiced by administrative theorists and practitioners for many decades. Over the years, reform traditions have developed and gained acceptance whose primary concerns were economy and efficiency and/or institutional responsiveness. Concern for these dimensions of performance is found in the literature on administrative reform whether one looks at the institutional reforms designed to organize authority efficiently and effectively within a single governmental unit, or whether one looks at the institutional reforms prescribed to organize the relationship between a number of governmental units within a metropolitan area.

The reform traditions that prescribed various institutional arrangements to enhance economy and efficiency in governmental operation 
and/or institutional responsiveness to citizen preferences and needs achieved a considerable degree of success in that many cities and metropolitan areas adopted structural changes. In light of this, it is particularly unfortunate that, until relatively recently, little empirical evidence has been supplied on the question of whether the various innovations in governance arrangements have had the desired impact on governmental performance. The purpose of this paper is to examine the major traditions of reform on urban governmental structure in terms of expectations and accomplish. ments. Over the past decade or so, enough empirical evidence has been reported to permit some assessment of the extent to which the expectations of the administrative reform traditions are being met. Since the problem of governmental performance is still much on the minds of public officials and citizens alike, such an assessment, and the conclusions drawn from it, are prerequisite to any consideration of altering the institutional arrangements of government in urban or metropolitan areas.

\section{Proposals for Governance Reform}

Three reform traditions characterize the thinking of theorists and practitioners in regard to improving the economy and efficiency of governmental performance and enhancing the responsiveness of public institutions to the preferences and needs of citizens for governmental goods and services. The "good government" movement was part of the progressive era and prescribed a particular institutional arrangement, city manager government, to achieve economy and efficiency in the governance of cities. ${ }^{1}$

Advocates of city manager government were concerned primarily with the internal organization and distribution of authority in urban governments. It was their belief that the graft, corruption and inefficiency that characterized the governance arrangements in numerous cities resulted from the mixing of politics and administration. As a result, these reformers prescribed a set of institutional arrangements that would effect a separation of politics and administration and would place the administration of government in the hands of professionally-trained and experienced managers. Such a separation would make government operation efficient and economical.

1Numerous texts present an overview of the municipal reform movement in general and the city manager plan of government in particular. One of the most concise overviews of city manager government appears in Ronald O. Loveride, City Managers in Legislative Politics (Indianapolis: Bobbs-Merrill Co., Inc., 1971), Chapter 2. For an historical perspective on the council-manager plan, see Harold Stone, et. al., City Manager Government in the United States (Chicago: Public Administration Service, 1940) and The Story of the Council-Manager Plan (New York: The National Municipal League, 1959 I. 
Although there is some disagreement over which city was the first to adopt the city manager plan of government, there is widespread agreement that the major thrust of the plan was to establish the primacy of economy and efficiency as criteria for evaluating the performance of government officials. To accomplish this objective, most city manager governments include the following standard features: popular election of a city council to perform the legislative function of government and appointment of a professional administrative officer, generally called a city manager, to run city government and implement the decisions of the legislative body. Under the plan, the legislative body restricts itself to matters of policy and politics and the administrator, or city manager, directs the dayto-day operation of city government. While other features of the plan were designed to reinforce the separation of politics from administration, ihe removal of the city's chief administrative official from popular election and his/her insulation from legislative policy-making were believed to be the best ways of enabling the administrative structure of municipal government to be run efficiently and economically. It was assumed that the person chosen by the legislature to run city government would be selected on the basis of professional qualifications, i. e., training and experience.

Data in the Municipal Year Book (s) published by the International City Management Association reflect on the popularity of the plan. In 1950, for example, $26 \%$ of cities with a population between 250,000 and 500,000 had adopted the manger plan of government; by $1958,39 \%$ of cities in this population group had changed to the manager form of government; by 1966 , the figure had risen to $48 \%$. Trends in the adoption of the manager plan are even more impressive among medium-sized cities, i. e., those with populations between 25,000 and 250,000 . By $1966,52 \%$ of cities in the 24,000 to 50,000 population group had adopted the manager plan of government; $53 \%$ of cities in the 50,000 to 100,000 group had adopted it; and $52 \%$ of cities in the 100,000 to 250,000 group had adopted it. Many of these adoptions came in the period after World War II as suburban communities incorporated and chose a form of government from among those found common at the time. ${ }^{2}$

2This brief summary of the adoption of city manager government does not attempt to explore variations among cities with the manager form of government. However, the growth of manager government is not randomly or uniformly distributed throughout the country. See, for example, Raymond Wolfinger and John O. Field, "Political Ethos and the Structure of City Government," 60 American Political Science Review (June 1966), pp. 306-326; and John Kessel, "Governmental Structure and Political Environment," 56 American Political Science Review (September 1962।, pp. 615-620. 
Reformers advocating city manager government were largely concerned with the organization and allocation of authority within urban governments. They did not, by and large, concern themselves with relationships among urban governments within the larger metropolitan areas.

Concern for the relationships among governmental units within a metropolitan area was expressed by the reform tradition advocating consolidation of governments in metropolitan areas. ${ }^{3}$ Consolidationists were concerned about the proliferation of governmental jurisdictions resulting from the metropolitanization of America. As governmental jurisdictions multiplied, so too did duplication of functions, overlapping of jurisdictional boundaries, and fragmentation of authority. These developments, consolidation theory holds, make it difficult to assign responsibility and accountability for governmental operation and increase the inefficiency and diseconomy of public goods and services produced and provided within the metropolitan region. Consolidationists were not unconcerned with the distribution of authority and responsibility within each governmental unit. In this respect many of their positions were similar to those of the good government reformers who advocated city manager government. However, the consolidation tradition went a step beyond the early municipal reform movement in its concern for the effects on governmental performance of multiplicity of governmental units within a metropolitan area. Hence, the reform prescription sought to deal with the inefficiency and diseconomy that resulted from the duplication of functions, overlapping jurisdictions, and fragmentation of authority that characterized growth of metropolitan areas.

Consolidation reformers advocated elimination of the numerous small units of government in a metropolitan area and the creation of a single, overall unit for the entire urban or metropolitan region. Within such an institutional arrangement administration would be organized into an integrated command structure in accordance with the basic principles of hierarchy. In addition, the number of popularly elected officials would be kept at a minimum and the function of administration would be separated from that of politics. ${ }^{4}$ Though these prescriptions were first written in 1925 , they were echoed in a major report issued by the Committee for Economic Development in $1966 .^{5}$

3The consolidation reform tradition is treated in William Anderson, American City Government (New York: Henry Holt and Co., 1925); The Units of Government in the United States: An Examination and Analysis (Chicago: Public Administration Service, 1942) ; and Modernizing Local Government (New York: Committee for Economic Development, 1966).

${ }^{4}$ See Anderson, American City Government, pp. 641-42.

${ }^{5}$ See Committee for Economic Development, Modernizing Local Government, pp. 11-12. 
Advocates of consolidation argued that adoption of their theory of governmental organization would cure the ills they had diagnosed as causing the inefficient and ineffective performance of government in metropolitan areas. They believed that consolidation of governmental units into a single, all-encompassing jurisdiction for the urban or metropolitan region would improve the output of public services (governmental performance), increase efficiency of production of public goods and services, and increase the responsibility and accountability of officials to citizens.

Adoptions of consolidated city-county governments have not occurred at anything near the frequency of adoptions of city manager government. Consolidations have been undertaken in Miami-Dade County, Florida, Nashville-Davidson County, Tennessee, Jacksonville-Duvall County, Florida, and Indianapolis-Marion County, Indiana. ${ }^{6}$ In virtually all other instances, voter response in consolidation referenda elections has been decidedly negative. ${ }^{7}$

The third major reform tradition in administration is represented by advocates of decentralization of governmental organizations. ${ }^{8}$ Essentially the antithesis of the consolidation tradition, the decentralization or community control tradition argues that large public institutions are inefficient, complex, cumbersome, and unresponsive to citizen preference and needs. In the place of such unwieldy and unresponsive structures, adherents of this tradition advocate the creation of multiple, smaller political units within the urban community. Such units of government would be more responsive to the diversity that characterizes most American cities and would enable citizens to exercise more direct control over decisions affecting the production and delivery of public goods and services, including decisions on the level of goods and services desired within a particular

6Studies of consolidation include Edward Sofen, The Miami Metropolitan Experiment (Bloomington: Indiana University Press, 1963); Brett Hawkins, Nashville Metro: The Politics of Consolidation (Nashville: Vanderbilt University Press, 1966); and David A. Booth, Metropolitics: The Nashville Consolidation (Lansing: Institute for Community Development, 1963).

${ }^{7}$ Conditions associated with consolidation are treated by Thomas R. Dye, "Urban Political Integration: Conditions Associated with Annexation in American Cities," 8 Midwest Journal of Politics (November 1964), pp. 430-464; and James A. Norton, "Referenda Voting in a Metropolitan Area," 16 Western Political Quarterly (March 1963), pp. 195-212.

${ }^{8}$ See, for example, Milton Kotler, Neighborhood Government: The Local Foundations of Political Life (Indianapolis: Bobbs-Merrill Co., Inc., 1969) and Alan Altschuler, Community Control: The Black Demand for Participation in Large American Cities (New York: Pegasus, 1970). 
neighborhood or area of the city. Under such an arrangement, each community or neighborhood would receive the level and mix of public goods and services that it desired, as well as exercise direct influence over the way in which public goods and services were produced. The net result of decentralization is that public institutions are managed by and responsive to the citizens whose needs they are supposed to meet.

Vincent Ostrom and Robert Bish have captured the essence of the differences between the consolidation and decentralization reform traditions:

The new reformers demanding community control over the provision of neighborhood public services within large urban areas clearly reject the propositions of increased size and reduced num. bers of jurisdictions to improved services, increased efficiency, increased responsibility of officials and increased confidence among citizens about their capacity to affect public policies. Instead, they see increasing consolidation leading to a deterioration in public services, reduced efficiency, decreasing responsibility among officials, and a decreasing confidence among citizens about their capacity to affect public policies. ${ }^{9}$

The decentralization reform tradition has advocated institutional change by the creation of community-based councils or neighborhood districts to effect better communications between citizens and government officials and to improve the provision of public goods and services. Over the past several years, a number of cities have adopted or considered charter provisions creating neighborhood councils or community boards. Among those cities with charter provisions creating decentralization, the City of Newton, Massachusetts, was the first to adopt a charter (approved by the voters in November, 1971) providing for neighborhood councils. ${ }^{10}$ The Charter Commission followed a major portion of suggested legislation developed by the Advisory Commission on Intergovernmental Relations. ${ }^{11}$ Subsequently, charter provisions for neighborhood decentralization were adopted in Honolulu, Detroit and Indianapolis. A number of other cities have similar charter provisions under consideration, while others have considered decentralization provisions and rejected them as part of charter revision. The varied charter proposals on decentralization set up some kind of elected body at the neighborhood level. Most give the board or

9Vincent Ostrom and Robert Bish, Understanding Urban Government: Metropolitan Reform Reconsidered (Washington: American Enterprise Institute, 1973), p. 12. 10"City Charter Provisions on Neighborhoods," Neighborhood Decentralization, January, 1974, pp. 1-3.

11Advisory Commission on Intergovernmental Relations, Legislative Program, 1970 Cumulative, Code 31-58-00. 
council mainly advisory powers, but in some instances the city council would have authority to delegate responsibility for certain municipal serv. ices. Admittedly, the powers of the neighborhood councils are not comprehensive, but in almost all instances they are more than presently exists at the neighborhood level.

\section{Accomplishments of Reform}

The reform traditions described in the previous section prescribed specific conditions, attributes or relationships of governance that the sponsor of each believed would contribute to economy and efficiency as well as to institutional responsiveness. The good government reformers argued that separation of politics from administration would accomplish their objectives; consolidationists argued that larger and fewer governmental units, along with professionalization of government, would remedy the ills of governmental institutions; supporters of decentralization advanced the view that greater and more extensive citizen participation was necessary to improve the delivery of services and enhance the responsiveness of governance institutions to citizen preferences and needs. A number of studies have been conducted and reported over the past decade or so that permit an assessment of whether the institutionalization of reform prescriptions has achieved the intended results.

Studies of city manager government have concluded that neither partner in the governance relationship, the manager or the council, has been willing or able to effect the intended separation between politics and administration. ${ }^{12}$ From the manager's perspective, politics and policy pervade most if not all administrative responsibilities. For example, preparation and submission to the council of the city's budget require judgments and decisions affecting existing and new policies. Then, too, there are political consequences in responding to requests from the council for recommendations to deal with specific problems. In short, a city's politics is very much a part of the manager's responsibility in administering the day-to-day operations of city government, unless the manager holds to a role conception that defines administration in extremely narrow, technical terms.

From the perspective of the city council, local legislators seem to be either unwilling or unable to stay out of administration and to restrict

12See Loveridge, op. cit.; Gladys M. Kammerer, et. al., City Manager Politics (Gainesville: University of Florida Press, 1962); Karl A. Bosworth, "The Manager is a Politician," 18 Public Administration Review (Summer 1958), pp. 216-222; and Jeffrey L. Pressman, "Preconditions of Mayoral Leadership," 66 American Political Science Review (June 1972), pp. 511-524. 
their activities to policy-making. For one thing, the job of city councillor is not a full-time one. Most city councillors hold down full-time jobs and have little or no understanding of urban problems and urban policy. In addition, they find it relatively easy to understand administration defined in terms of levels of specific services, e. g., snow removal, garbage collection, etc., within their own wards and/or neighborhoods. Under these conditions it is hardly surprising that a disproportionate amount of the councillor's time is devoted to administrative activities that could, and perhaps should, be left to the city manager, while the broader, more complex and time-consuming issues of urban policy are neglected. Another feature of manager government that has contributed to the overlap rather than separation between administration and politics is the readiness of candidates for city council to campaign on the issue of the manager's tenure, personality, administrative practices, etc. Managers often find themselves the focal point of an electoral campaign, with some candidates promising to fire him/her and others promising to support him $/$ her. ${ }^{13}$

A number of studies have been reported casting doubt on some major expectations of the consolidation reform tradition. For example, data comparing cities in different population groups with average per capita expenditures for each group reveal a direct, rather than indirect, relationship between city size and expenditure, i. e., as city size increases, per capita expenditures increase. ${ }^{14}$ This is exactly the reverse of the relationship expected by advocates of governmental consolidation. They had advanced the view that increasing the size of governmental jurisdictions would result in lower per capita expenditures. A major study by Roy Bahl reveals a positive relationship between increasing city size and increasing per capita expenditures. ${ }^{15}$ Finally, studies of the provision of police services reveal that a number of small governmental units are able to provide

13The role of the city councillor is treated by Kenneth Prewitt, The Recruitment of Political Leaders: A Study of Citizen Politicians (Indianapolis: Bobbs-Merrill Co., Inc., 1970); Heinz Eulau and Kenneth Prewitt, Labyrinths of Democracy: Adaptations, Linkages, Representation and Policies in Urban Politics (Indianapolis: BobbsMerrill Co., Inc., 1973) : Jeptha Carrell, "The City Manager and His Council: Sources of Conflict," 22 Public Administration Review (December 1962), pp. 203.208; and C. A. Harrell and D. G. Weiford, "The City Manager and the Policy Process," 19 Public Administration Review (Spring 1959), pp. 101-107.

14U. S. Bureau of the Census, City Government Finances in $1966-67$ and 1970-71 (Washington: U. S. Government Printing Office).

15Roy W. Bahl, Metropolitan City Expenditures: A Comparative Analysis (Lexington: University of Kentucky Press, 1969). 
police services at lower or similar per capita costs to those incurred in the provision of police services by a single, large jurisdiction. ${ }^{16}$

The consolidation assumption concerning the relationship between the multiplicity of jurisdictions and per capita costs has also been the subject of investigation. Bahl included the number of jurisdictions in a metropolitan area as a measure of multiplicity in a seventeen variable statistical analysis of 1960 expenditures in 198 American cities. He found that the number of governmental units accounted for very little difference in per capita operating expenditures from one metropolitan area to another. What little difference he did find indicated that the larger the number of governmental units, the lower the per capita expenditure. This is exactly the opposite of the consolidationist assumption. ${ }^{17}$

The reform traditions advocating city manager government and consolidation assumed that these institutional arrangements would result in a high degree of professionalization of governmental institutions. Professionalization of administrative personnel would improve governmental performance by permitting greater specialization, uniformity, and reliability in the production and provision of services.

Recent studies have cast serious doubt on the beneficial consequences that are supposed to accrue from professionalization of public bureaucracies. Studies of professional educators, for example, conclude that teachers have neither the knowledge nor the concern to improve the educational performance of students of cultural backgrounds different from their own. Instead, professional educators have been found to resist change in educational policy-making arrangements and to insulate the producers of education - the teachers and administrators - from the consumers the students, parents, and community. ${ }^{18}$ Studies of the relationship between professionals and their clients in the area of social welfare programs conclude that professionals may lack both knowledge and concern for their

16Elinor Ostrom and Roger Parks, "Suburban Police Departments: Too Many and Too Small," in Louis Masotti and Jeffrey Hadden (eds.), 7 Urban Affairs Annual Reviews: The Urbanization of the Suburbs (Beverly Hills: Sage Publications, 1973) and Elinor Ostrom, et. al., Community Organization and the Provision of Police Services, Sage Professional Papers in Administrative and Policy Studies, 03-001, 1973.

${ }^{17}$ Bahl, op. cit., pp. 62-68.

18The impact of professionalization has been studied by Marilyn Gittell, "Decision-Making in the Schools: New York City, A Case Study," in Gittell (ed.), Educating an Urban Population (Beverly Hills: Sage Publications, 1967); Marilyn Gittell and Mario Fantini, Decentralization: Achieving Reform (New York: Praeger Publishers, 1973) ; David Rogers, 110 Livingston Street (New York: Random House, 1968); and Dennis Palumbo and Richard Styskal, "Professionalism and Receptivity to Change," 18 American Journal of Political Science (May 1974), pp. 385-394. 
clients. ${ }^{19}$ The process of professionalization appears to have as much potential for affecting governmental performance negatively as it does for affecting it positively.

A number of governance and decision-making arrangements have been developed and utilized to accomplish the objectives of the decentraliza. tion reform tradition. Included among these arrangements are experiments with community control of urban schools and citizen participation on antipoverty boards, urban renewal boards, planning bodies, etc. The few studies conducted of these arrangements have revealed a number of serious structural and procedural problems. These problems have prevented realization of widespread and effective citizen participation in public policymaking arrangements.

Decentralization of urban schools has been undertaken in Detroit and New York City. In both cases, elementary and junior high schools are governed by community boards elected by and from the residents of the various school districts. Certain powers are delegated to the local district boards, though a central board is retained and has the power to review and, in most instances, override local board decisions. Two factors have impaired the effective operation of community control of schools in Detroit and New York City. First, state legislation authorizing creation of the community school systems failed to grant local school boards the full extent of decision-making authority that had been recommended by the study commissions. In New York City, for example, the central board of education is authorized to suspend, remove, or supersede a community school board or remove any of its members. Beyond that, the central board retains extensive financial and personnel powers, including the preparation of the capital budget and the disciplining and licensing of teachers. In addition, the decentralization statute contains a number of ambiguities relative to the powers of the community boards. In Detroit, the central board retains similar authority over the eight regional boards, including the power to review personnel decisions made by the regional boards and the responsibility to allocate capital funds. In both Detroit and New York City, community and regional boards have been granted authority over curricular matters, but that authority is constrained by guidelines estab. lished and enforced by each city's central board of education.

A second factor impairing the effectiveness of decentralization of education is the low rate of participation in community school board

19Frances Fox Piven and Richard A. Cloward, Regulating the Poor (New York: Pantheon, 1971 ) and Neil Gilbert, Clients and Constituents: Community Action in the War on Poverty (San Francisco: Jossey-Bass, 1970). 
elections. Supporters of community control of schools in Detroit and New York City have encountered serious difficulties in trying to involve residents of school districts in district board elections. The credibility of antipoverty boards has also been compromised by the low rate of participation in elections. For example, poverty board elections in New York City in the mid-1960s produced a five per cent voter turnout.

Case studies of community action agencies created under antipoverty programs have identified a number of impediments to effective citizen participation in public policy-making arrangements. In addition to the generally low voter turnout in poverty board elections, community action agencies have foundered on essentially internal organizational problems. The availability of responsible local leadership, disagreement over who represents the poor, conflicts over program priorities, and disagreement over whether anti-poverty agencies should emphasize services or organization are some of the issues that have impaired the effective opera. tion of decentralized decision-making organization. ${ }^{20}$

\section{Alternatives to Governance Reform}

The reform traditions discussed thus far have all prescribed changing the formal governance arrangements in urban and/or metropolitan areas to realize economy and efficiency and institutional responsiveness. Good government reformers prescribed city manager government; consolidationists favored a single, large area-wide unit of government for the entire metropolitan region; and decentralizationists prescribed the creation of numerous, small political units within cities.

Two features of structural change are relevant to this analysis. First, each of the institutional arrangements prescribed by the administrative reform traditions involves a fairly complex set of procedures. For example, in most states the process of charter revision - changing from an existing form of government to another one-requires approval of the city's electorate to create the charter revising body, approval of state officials - usually the governor and sometimes the state legislature - for the revised charter, and a second election of the city's voters to approve the new charter. Consolidation of governmental units within a metropolitan area is no less involved. Again, there is usually a requirement that residents affected by the consolidation proposal, both in and outside the

20See Ralph Kramer, Participation of the Poor: Comparative Case Studies on the War on Poverty (Englewood Cliffs: Prentice-Hall, Inc., 1969) and Paul E. Peterson, "Forms of Representation: Participation of the Poor in the Community Action Program," 64 American Political Science Review (June 1970I, pp. 491-507. 
central city, must approve it in a general or special election. Then, too, approval of state officials, especially the legislature, must be gotten. Given the tensions that have traditionally characterized relations between urban, rural, and suburban state legislators, such approval is not easy to get. Decentralization also involves a fairly complex set of procedures. At a minimum, decentralization provisions proposed by city governments undergo scrutiny and action at the state level. The experience of New York City in gaining the approval of the state legislature to decentralize the city school system is an excellent example of what can happen to such proposals in the state's legislative arena. Some cities have attempted to undertake decentralization through the process of charter revision. A few have found that the revised charter has failed to gain voter approval because of disagreement among the electorate concerning the desirability of decentralization.

Second, each of the structural changes prescribed by administrative reformers possesses a considerable degree of permanence. It is relatively difficult to modify or reverse any of the prescribed institutional arrangements once they have been implemented. Hence, commitment to institutional change must be substantial, and belief in its workability considerable, before public officials advance the view that the performance of public institutions can be improved by new governance arrangements. Once such arrangements have been implemented there are numerous political and economic constraints that preclude modification or termination of the new arrangements.

In light of the record of accomplishments reviewed in the previous section, it is reasonable to question whether the governance arrangements advanced by the administrative reformer traditions are the most practical means by which to improve governmental performance. There is sufficient evidence to support the view that city manager government has not improved the economy and efficiency of government by separating politics from administration; that consolidation of governmental jurisdictions has not resulted in consistently lower per capita costs of public services and general operation of government; that professionalization of public institutions has not improved the quality of public personnel; and that decentralization has not improved the responsiveness of public institutions to citizen preferences or contributed to effective and widespread citizen participation in policy-making.

Advocates of public choice theory have advanced the view that the goals of administrative reformers can be realized by a variety of adminis. trative arrangements within and among governmental units that do not 
require formal alteration of governance arrangements. ${ }^{21}$ Such arrangements would avoid or at least minimize the high political and economic commitments, costs, and risks inherent in charter revision, consolidation, and decentralization. Furthermore, the administrative arrangements suggested by public choice theory are relatively simple to institute and, consequently, easier to modify or terminate if intended results fail to materialize. In short, they could be characterized as reversible rather than permanent.

A number of cities have experimented with one such administrative arrangement, known variously as "little city halls" or "neighborhood city halls." ${ }^{2}$ In addition to recommending changes in city service delivery arrangements, neighborhood city halls were designed to insure that city services are provided in a manner that is relatively responsive to local preferences and needs; they provide information regarding the availability of specific services, and promote action at the neighborhood level to increase participation in community projects. Thus, the neighborhood city hall program combines both objectives of the traditional reform movements. It attempts to bring about some measure of economy and efficiency into the production and delivery of city services to local neighborhoods and to enhance the responsiveness of the public bureaucracy to local needs and preferences.

A variation on the neighborhood city hall concept is the Neighborhood Service Program developed and begun in the city of Flint, Michigan. The NSP will provide residents of Flint a specific contact point with the city within their local neighborhood. It will provide a focal point for Flint residents to request service assistance and a follow-up procedure through which city officials can determine the quality of services being provided. The NSP is organized around an operating community school program, so that neighborhood service representatives will be located in approximately twenty selected community schools. The major advantage of using the community schools is that substantial numbers of city residents already

${ }^{21}$ One of the best statements of public choice theory is Robert Bish, The Public Economy of Metropolitan Areas (Chicago: Markham Publishing Co., 1971). See, too, Bish and Ostrom, Understanding Urban Government, op. cit., for a comparison of the public choice approach to metropolitan reform proposals.

${ }^{22}$ See, for example, Eric A. Nordlinger, Decentralizing the City: A Study of Boston's Little City Halls (Cambridge: M. I. T. Press, 1974); Neil Lawer, "Boston's Little City Hall Program," 31 Public Administration Review (July/August 1971), pp. 456-457; Robert K. Yin and Douglas Yates, Street-Level Government: Assessing Decentralization and Urban Services (Santa Monica: Rand Corporation, 1974); and Joseph Zimmerman, The Federated City (New York: St. Martin's Press, 1972), Chapter III for a discussion of various administrative responses to the problem of communication gaps between citizens and city hall. 
participate in a variety of extended educational and recreational services offered through the community school system, so that the schools offer a ready-made vehicle of considerable public access to the NSP. The program, it is hoped, will promote better school-city relations at the neighborhood level and increase communications among the city, the schools, and neighborhood residents.

Little city halls, neighborhood service programs, and similar kinds of administrative arrangements to establish closer and more direct linkages between public institutions and their clientele offer a viable alternative to governance reform. At the same time that these arrangements seek to accomplish the goals of the administrative reform traditions reviewed earlier in this paper, they do so without the political and financial commitments and risks that characterize formal institutional change. While there is much that can be said for city manager government, city-county consolidation, and decentralization, the record of their accomplishments is not compelling enough to persuade administrative theorists or practitioners that the objectives of economy and efficiency and institutional responsiveness have been uniformly and consistently achieved by these governance reforms. On the contrary, the available evidence casts considerable doubt on this question.

Given the record of accomplishments of these reform traditions, public administrators seeking to improve governmental performance by increasing the economy and efficiency of public service production and provision, as well as increasing the responsiveness of public institutions to the preferences and needs of their clientele, might be on firmer ground with governance arrangements that experiment with the administrative rather than the political framework of governmental institutions. ${ }^{23}$ Public choice theorists undoubtedly would support the view that administrative arrangements such as neighborhood service programs, little city halls, etc., offer considerable opportunity for improving governmental performance without making the irreversible commitments inherent in altering formal governance arrangements.

23Altschuler, op. cit., p. 64, distinguishes between "political" and "administrative" decentralization. This distinction might prove useful in evaluating the nature and extent of alternative governance arrangements. 